УДК 327(510)"1948/1949"

HE Yanqing, Ph. D.

\title{
THE BEGINNINGS OF PRC'S DIPLOMACY: DIPLOMATIC ACTIVITY OF THE CHINESE COMMUNIST REGIME IN THE XIBAIPO PERIOD - MAY 1948 TO MARCH 1949
}

\begin{abstract}
Diplomatic activities of the Chinese Communist Regime in the Xibaipo period constitute the beginning of PRC's diplomacy. In this period, Chinese Communist leaders reexamined the international situation and decided to form a strategic alliance with the Soviet Union. At the same time, they also laid down the basic principles of PRC's diplomatic policy and established the organizational structure of the PRC's diplomatic system. Most of the diplomats in the early days of new China were trained in the war fighting against CCP's enemies inside or outside of China. From then on, the CCP gradually turned the spontaneous contacts with other countries into a national diplomacy with state conscious and colorful skills.
\end{abstract}

Key words: Xibaipo period, PRC diplomacy, Sino-Soviet relations, Sino-US relations

Xibaipo is a small mountain village in the central part of Pingshan County, Hebei Province of China. During the Civil War in China, due to the circumstances of war, the Chinese Communist Party's (CCP) leaders decided to move their central party organs from Yan'an, Shaanxi Province, to Xibaipo in May 1948. It was from this small village that Chairman Mao Zedong and the Central Committee of CCP waged three of the most famous battles during the last phase of the Civil War - the Liaoshen, Pingjin and Huaihai battles. The CCP's army successfully won all three battles and finally laid the foundations for national victory. The Seventh Central Committee of CCP convened its Second Plenary Session, in order to plan for the establishment of the government of China. The CCP also convened a National Land Conference in the village and formulated the basic principles of China's land policy. In March 1949, after ending the Second Plenary Session, the Central Committee of CCP left Xibaipo for Beiping. This period is often referred to as the "Xibaipo period" (form May 1948 to March 1949) in the history of the CCP.

For a long time, scholars researching this period of the CCP's diplomatic history often focused on one event, the visit of a member of the CC CPSU, Anastas Mikoyan to Xibaipo village, where he discussed different issues with 
the CCP leaders. ${ }^{1}$ Most of these scholars argued that this visit marked the initial establishment of the Sino-Soviet alliance. In addition, the Ward Case that happened in Shenyang - the biggest city in Northeast China also drew a lot of attention. ${ }^{2}$ But few scholars explored CCP's diplomatic activity in this period as a whole or studied foreign policy patterns formulated by this activity. This paper is largely focused on exploring the diplomatic activities of the CCP during this period. Considering the changes that took place in CCP's international strategy, the formulation of basic diplomatic principles and structuring of diplomatic institutions, as well as the training of diplomats, it can be said that the diplomatic activities of this period do constitute the beginning of PRC's diplomacy.

\section{From the "intermediate zone" to "leaning to one side" - formulation of PRC's basic international strategy}

Due to the Soviet attitude towards the CCP in the early days after the end of the Second World War, Mao Zedong and other CCP leaders decided to put forward the strategic theory of the "intermediate zone". The Soviet Union's postwar policy was to maintain the alliance with the West and ultimately form a partnership. Through cooperation with western countries, Moscow could consolidate and extend political rights it obtained in Yalta and at Potsdam. In the Far East, Stalin's strategic objectives revolved around two issues: firstly, preserving the independence of Outer Mongolia from China as means to ensure broad security of the Soviet Union; secondly, restoring Russian influence in Manchuria as a way to provide the Soviet Union with an ice-free port in the Pacific. The demands of the Soviet Union at the Yalta conference had been recognized by

1 In 1995, the Publication Far East Problems which belongs to the Far East Institute of Russian Sciences Academy published Andrei Ledovski's article - “Секретная миссия А. И. Микояна в Китай (январь-февраль 1949 г.)”, Проблемы Дальнего Востока, 1995, № 2, 3. Since then, with the decryption process of Russian archives, historians have done a lot of research on Mikoyan's visit to Xibaipo. One of the most major articles on this topic in China was written by Xue Xiantian and Wang Jin: “The Problems about Mikoyan's Visit to Xibaipo-Review of Ledovski's Article Mikoyan's Secret Visit", Modern Chinese History Studies, Vol. 3, pp. 147-164. As more Russian documents had been declassified, more history research papers and books came out. In 2009, professor Shen Zhihua used the latest declassified Russian archives and wrote two articles which basically explained the issues regarding Mikoyan's visit. Shen Zhihua, "Hard-seeking Meeting: The Tests and Communications Between The Leaders of CPSU and CPC: The Discussion on The Background and Foundation of The Sino-Soviet Alliance (Part I)", Journal of East China Normal University, Vol. 1, 2009, pp. 1-13. Shen Zhihua, "From Xibaipo to Moscow - Mao Zedong's Decision to Lean to the Side of the Soviet Union: The Discussion on the Background and Foundation of the Sino-Soviet Alliance (Part II)", The CCP History Studies, Vol. 4, 2009, pp. 14-33. Shen studiously described Mikoyan's visit from its beginning to its end and analyzed the reasons and approaches leading to the establishment of the Sino-Soviet Alliance. Shen believed that Mikoyan's visit in 1949 had made Stalin understand the CCP's intentions in China and on the world stage due to the same ideology shared by the CCP and the CPSU.

2 Researchers who explored this event hope to discover relations pertaining to it, including the relations between the CCP's Northeast Bureau and the Soviet government, and the relations between the CCP's regime and Washington. One of the famous accomplishments is Yang Kuisong's article. Yang Kuisong, "The Ward Case and the PRC's Policies towards the United States", Historical Research, Vol. 5, 1994, pp. 104-118. 
the Western powers and the Chiang Kai-shek government. The Soviet Union and the KMT government signed the "Sino-Soviet Treaty of Friendship and Alliance". In return, Stalin was ready to support Chiang Kai-shek's KMT government and discourage CCP's revolutionary activities. ${ }^{3}$ In view of this, the CCP had to be self-reliant, and create a new path to establish its authority. Mao Zedong used a vivid argument, dubbing the CCP struggle as one of the revolutions in the "intermediate zone".

In August 1946, when he was interviewed by the American journalist Anna Louise Strong, Mao put forward his theory: "The United States and the Soviet Union are separated by an extremely vast area, there are so many countries of Europe, Asia, and Africa. Some of them are capitalist countries; others are colonial or semi-colonial countries. Before conquering all of these countries, the reactionaries in the United States cannot attack the Soviet Union." ${ }^{4}$ This vast area was the "intermediate zone" and China was part of it. So, the CCP's struggle for power should and must be done independently, as it would prove helpful for the interests of the socialist camp. Mao's theory was the ideological base of the CCP's internal and foreign policy issues during the Civil War. Some scholars believed that by putting forward this theory Mao signaled for the first time, his independence from the rules established by the great powers, particularly the U.S. and the USSR. In this way, he set down an independent strategy inside the international system with respect to both big powers. ${ }^{5}$ However, I would argue that Mao's theory of the "intermediate zone" was one of his tactics used at a time when Moscow could not directly support the Chinese revolution. Thus, when the situation inside or outside China changed, Mao and the CCP changed their foreign policy accordingly.

In June 1947 when the Marshall Plan was introduced by the United States, Moscow reacted strongly. In order to counter the influence of the Marshall Plan and enhance its own influence among the Eastern European countries, the Soviet government respectively signed bilateral trade agreements with six of these countries (Romania, Bulgaria, Czechoslovakia, Poland, East Germany and Hungary) from July $10^{\text {th }}$ to August $26^{\text {th }}$, thus implementing the "Molotov Plan". The Soviet Union's foreign policy strategy had also changed when it established the Communist Information Bureau (Cominform) as the coordinating center for all communist parties and workers' parties around the world. The confrontational policies of both the USA and the USSR greatly accelerated the process of setting up two distinct blocs. Ultimately, two camps, each with its own isolated, parallel economic systems and fundamentally hostile political concepts appeared in Europe. The Cold War between the USA and the USSR swept through Europe and began to spread to other parts of the world.

Inside China, the KMT government signed a treaty with the U.S. government named the "Sino-US. Treaty of Friendship, Commerce and Navigation" in November

3 Shen Zhihua, "The Soviet Union Sent Troops in Northeast China: Goals and Ends", Historical Research, Vol. 5, 1994, pp. 88-103.

4 Mao Zedong, “The Interview by American Journalist Anna Louise Strong”, Selected Works of Mao Zedong, Beijing: People's Publishing House, 1991, p. 1193.

5 Yang Kuisong, The Revolution in the Intermediate Zone - Evolution of the Tactics of the Chinese Revolution in the International Context, Central Party School Press, 1992, pp. 442-443. 
1946. Along with this treaty Washington and the KMT government concluded a series of agreements or secret agreements that protected the dominant American position pertaining to Chinese politics, economy, military etc. The stance od the CCP on this treaty was that it was an arrangement that allowed American capital to fully occupy China, to overrun Chinese national industry and commerce, and ultimately to transform the whole of China into one of American's new "colonies". After all, it was an unequal treaty. The CCP believed that the signing of this treaty meant that the KMT government had implemented its own "one-sided" policy, tying itself to the chariot of the U.S., which would result with anti-Soviet, antiCommunist policies and leaning to the side of the Americans.

Mao Zedong delivered a speech on this issue at the CCP Central Committee meeting on December 25, 1947. Mao pointed out that the "Soviet-led antiimperialist camp had been formed. As a socialist country, there was no economic crisis in the Soviet Union. The Soviets had a strong upward mobility which was cherished by the majority of the people around the world. In contrast, the biggest capitalist country - the United States went through a lot of economic crises. So, it was on a serious downward decline and it was also opposed by the majority of the people around the world." ${ }^{6}$ In addition, he said: "We will cooperate with the truly democratic forces in the world. As long as all of us do our best, we can defeat the conspiracies planned by imperialist countries, we can also successfully prevent the Third World War when we overthrow the oppression imposed by the reactionaries on the people. At last, we can achieve permanent peace". It was obvious that at the time when Mao made this speech, the CCP aligned itself with the socialist bloc.

In April 1948, after the CCP's central party organs had moved into Xibaipo, the People's Liberation Army launched a comprehensive counterattack on the mainland that signaled a nationwide victory for the communists. Therefore, the CCP leaders began to outline a blueprint for a new China, which also implied the establishment of a new government. On November 14, the Xinhua News Agency, which had been the voice of CCP since 1931 published one of Mao Zedong's review articles: "A Major Change in the Military Situation in China". This article pointed out: "We had originally estimated that it would take about five years to completely overthrow the KMT reactionary government from July 1946. Now, it seems that we could throw them out in a year or so from now ". 8 After the success of the Chinese Revolution, the most important task of the CCP was domestic reconstruction. But economic reconstruction in China became a new issue for the CCP leadership. Mao and other leaders believed that they required international aid in order to achieve the goal of reconstructing China. Since the beginning of the Chinese Civil War, the CCP leaders had already recognized the United States government as the sponsor of the KMT government and had named them the "America-Chiang" group. So they did not expect that

6 Mao Zedong, “Current Situation and Our Mission”, Selected Works of Mao Zedong, Beijing: People’s Publishing House, 1991, p. 1259.

$7 \quad$ Ibid., p. 1260.

8 The Literature Research Center of the CPC Central Committee, Mao Zedong Chronicle, 1893-1949 (Vol. 2), Beijing: The Central Literature Press, 2002, p. 389. 
the People's Republic of China could receive any aid from the United States, ${ }^{9}$ but they hoped they could receive aid from the Soviet Union due to the obvious ideological affinity.

On September 13, 1948, Mao gave a speech on China's future development at the Politburo meeting of the CC CCP. He said that "complete independence of the Chinese economy could not be achieved in ten or twenty years" and "the Soviet Union would help us prepare for the transition from New Democracy to Socialism. At first, the Soviets would help us develop our economy". ${ }^{10}$ But in fact Mao and other CCP leaders were not completely confident that they would receive Soviet aid. At that time, they were still concerned about the Soviet stance towards the revolution in China and the policy of the CCP. Because of the frequent capriciousness in Soviet's policy towards China, ${ }^{11}$ the CCP was concerned whether the Soviet government would give open support to the People's Republic of China after the revolution. Could the Soviet Union accept New China as one of its main allies and one of the key members of the socialist camp?

During the Xibaipo period, the most important diplomatic activities of the CCP leaders pertaining to the construction of New China's international strategy were connected to defining the close relationship with the Soviet Union. Mao and other CCP leaders were keen to establish close high-level contacts with the leaders of the Soviet Union. They were eager to get official recognition from Kremlin, as well as, to receive Moscow's commitment regarding aid for reconstruction. On April 26, 1948, a few days after the CCP's central party organs moved into Xibaipo, Mao expressed his wish to Stalin to visit the Soviet Union. ${ }^{12}$ Mao directly indicated that the main purpose of his visit to the Soviet Union was to "listen to the advice of the Soviet Communist Party in political, military, economic and other important fields". In addition, he also wanted to explore Soviet military, economic, administrative,

9 There has always been a lot of debate among scholars regarding this issue.. The main topic among American historians was the 'Loss of China' argument and the 'Lost Chance' argument. Some American researchers believed that there were some opportunities for a normalization of Sino-American relations after the establishment of the Central Government of the PRC. However, because of ideological differences, and the troubled history of mutual contacts, together with the pressure applied by the Soviets on the CCP, the CCP government and Washington could not materialize these opportunities. I do not share this view. According to my research, there were no such opportunities during the founding years of the PRC.

10 The Literature Research Center of the CPC Central Committee, Collected Works of Mao Zedong (Vol. 5), Beijing: People's Publishing House, 1996, p. 146.

11 The changing process of the Soviet policy towards China has been interpreted by some Chinese historians, see: Shen Zhihua ed., History of Sino-Soviet relations, 1917-1991, Beijing: New China Press, 2007; Xue Xiantian and Kim Donggil, History of Sino-Soviet Relations During the Republic of China Period, Beijing: The CPC History Press, 2009; Niu Jun, "The Complex Relationships Among the KMT, CPC, The Soviet Union and The United States from 1945 to 1949", Historical Research, Vol. 2, 2002, pp. 84-103; Yang Kuisong, Friendship and Hostility between Mao Zedong and Moscow, Nanchang: Jiangxi People's Republishing House, 2008.

12 There have been some disputes in the academic circles about the specific time of Mao Zedong's first request to visit the Soviet Union. Some researchers pointed out that when Hu Zongnan's troops attacked Yan'an in March, 1947, Mao Zedong sent a telegram to Stalin and asked to visit Moscow. But some other researchers, like Shen Zhihua, believe that this request was first made by the Soviet leadership. 
and party policies. ${ }^{13}$ However, Stalin asked Mao to postpone his visit for various reasons. ${ }^{14}$

Nevertheless, while trying to close an alliance with the Soviet Union, the CCP at the same time still maintained its independence and adhered to its own interests. It was this very firmness of the CCP's stance and insistence on their own opinion that made Stalin realize the true strength of the CCP, thus dictating the necessity for a high-level meeting between the CPSU and the CCP. On January $14^{\text {th }}$, Stalin sent Mao a telegram that said: "Since you have to stay in China at present, we can immediately send a Politburo member to your country, if you agree. He could meet you in Harbin or where you choose and talk with you about any problems you would be interested in". 15 The CCP soon expressed its interest and extended its welcome. So Mikoyan, one of the CPSU Politburo members, finally arrived to Xibaipo on January 30,1949. These were the first direct talks between the leaders of two communist parties.

Mikoyan's visit gave Soviet leaders a chance to intuitively understand the state of China's internal politics, economy, diplomacy and other fields. It also gave the CCP leaders a chance to understand the true stance of the CPSU towards the Chinese Revolution. Firstly, Mikoyan praised the victory of the Chinese Revolution and the CCP's outstanding leadership. Secondly, he conveyed the CPSU's position on the problems concerning Mongolia, Xinjiang, Northeast of China, etc. As for Mongolia, the CPSU insisted on the independence of Outer Mongolia and believed it had become a fact during the years of the Republic of China. In Xinjiang, the CPSU neither wanted to provide impetus to the independence movement nor hoped to take control of any part of Xinjiang. In Northeast China, the CPSU admitted that the Sino-Soviet Agreement about Port Arthur was an unequal treaty which was signed by the KMT government and the Soviet government in 1945. In addition, the Soviet government was prepared to cancel this treaty and withdraw its army from Port Arthur. ${ }^{16}$ Thirdly, Mikoyan listened to several CCP's high level officials reporting about the CCP's policies on many domestic and foreign issues and he made some comments and gave some advice. For example, when he talked with Mao and some other leaders, Mikoyan said: "In my opinion, the CCP shouldn't join the Cominform. You should form an East Asian international communist organization which would

13 "Mao Zedong's telegram to Stalin on a visit to the Soviet Union", April 6, 1948. АПРФ, Ф. 38, оп. 1, д. 31, л. 32; Русско-китайские отношения в ХХ веке, Т. V, К. 1, с. 417.

14 Stalin repeatedly postponed Mao's visit to the Soviet Union for two reasons: firstly, Stalin was afraid that the news about Mao's visit would be leaked. If this happened, the Western countries would have enough excuse to accuse Mao of being Moscow's agent. It would do harm to the CCP's prestige in China. Secondly, Stalin hoped that Mao would visit the Soviet Union as the Head of the formal government of China after the founding of the new regime. If this was the case, the visit would raise the prestige and confidence of the CCP. It would have a major international significance. This can see in A. M. Ledovski, Chen Chunhua trans., Stalin and China, Beijing: New China Press, 2001, p. 59.

15 "Stalin's telegram to Mao on peaceful negotiations between the CPC and the KMT, January 14, 1949. АПРФ, ф. 39, оп. 1, д. 31, л. 69; ф. 45, оп. 1, д. 330, л. 110-113, Русско-китайские отношения в ХХ веке, Т. V, К. 2, с. 21-22.

16 "Mikoyan's Report to the Politburo of the CPSU: My Visit to China in January-February, 1949", September 22, 1960, АПРФ, ф. 3, оп. 65, д. 606, л. 1-17; Проблемы дальнего востока, 1995, № 2, c. 96-111. 
be led just by you. You-the CCP, the Japanese Communist Party and the Workers Party of Korea should be its initial members. It would absorb other communist parties in Asia later". Then Mao asked him whether the CCP could make contact with the CPSU directly or not, and Mikoyan answered positively. ${ }^{17}$ Mikoyan, therefore, on behalf of the Central Committee of the CPSU, accepted the CCP as an important member of the socialist camp, and they started to resume their responsibility inside the camp. The attitude of the Soviet Union, which implied satisfying CCP's demands with regards to its national interests and international status, only strengthened its willingness to form an alliance with the Soviet Union.

While pursuing the realization of talks with the leaders of the CPSU, the CCP complied with Soviet foreign policy interests as much as possible, especially when it came to the relations with the United States. In Northeast China where the rule of the CCP was stable, this tendency of complying with Soviet demands in foreign affairs was very obvious. In late October and early November, 1948, during the process of taking over the most important city in Northeast China, Shenyang, by the CCP's Northeast Bureau, the American, British and French consulates were treated relatively mildly by the CCP officials according to "The Directive of the CCP's Central Committee on Treating Foreigners in China" which had been issued on February 7, 1948. ${ }^{18}$ The Soviet Union, however, was not satisfied with this state and told the CPC officials: "Chinese people are too polite to the United States". The delegates of the CPSU in Northeast China suggested to the CCP leaders that they should block the American consulate, restrict the consulate staff's freedom of movement and confiscate its radio transmitter. It was said that Stalin also agreed with these suggestions. ${ }^{19}$

So, after the liberation of Shenyang early in November, the CCP's Central Committee instructed the NortheastBureau to negotiate with Sovietrepresentatives in Shenyang, listen to their advice and correct the method of treating Americans. The local officials of the CCP were asked to abandon their fantasies about friendship with the Americans and strive to 'squeeze out' the American, British and French consulates by making it difficult for them to work so they would leave China. Consequently, the Ward Case happened, which was obviously planned by the CCP's officials to force the Americans out of China. ${ }^{20}$ During their meeting with

17 "Memorandum of The Conversation Between Mikoyan and Mao Tse-tung About the Foreign Relations and Historical Problems", February 2, 1949, АПРФ, ф. 39, оп. 1, д. 39, л. 47-53; Русскокитайские отношения в ХХ веке, Т. V, К. 2, с. 62-66.

18 On February 7, 1948, the Central Committee of CCP issued The Directive of the CPC's Central Committee on Treating Foreigners in China. It asked the army and the local CCP authorities to protect all foreign representative bodies in China, whether they were imperialist institutions or not. It pointed out: "If the consulates of any foreign counties would want to negotiate with us to protect their citizens' interests, we must regard their negotiators as diplomatic representatives and protect their legitimate rights, regardless of fact whether their countries had recognized our army and regime or not." The State Archives Administration of the People's Republic of China, Collected Documents of The CPC Central Committee (1948-1949), Beijing: The Central Party School Press, 1987, p. 23.

19 C. H. Gangchalov, Chen Chunhua (trans.), "Interview of Kovalev on the conversation between Stalin and Mao Zedong", National History Research Resources, Vol. 1, 1993.

20 Professor Yang Kuisong has analyzed this case thoroughly from the start to the end. Yang Kuisong, “The Ward Case and PRC's Policies Regarding the United States”, Historical Research, Vol. 5, 1994, pp. 104-118. 
Mikoyan, the CCP leaders repeatedly explained their stance towards the United States. They said: "In the three years after the Second World War, the prestige of the United States has declined drastically in China. In general, the people of China hate America. To tell the truth, most progressive people like us are frightened by its power." They also told Mikoyan about the "squeezing out policy" in Northeast China: "The foreign consulates (American, British and French) hinted that they were unwilling to leave China and that they wanted to establish true friendship with us...But we didn't want to see them in Shenyang. So, we took measures to isolate them, make them feel bad. At last, they had to retreat from Shenyang." ${ }^{21}$

Undoubtedly, the attitude toward the United States which the CCP deliberately displayed to the Soviets made them very satisfied. Although Mikoyan sometimes indicated that it should also refer to treating foreign capital in China: "CPC's new government should nationalize all Japanese capital, French capital and even most of the British capital as soon as possible". And "you should implement cautious policies towards the American capital... only after your new government controlled the overall situation in China, you could make a final decision about the American capital according to the current situation and the Americans' attitude". ${ }^{22}$ But this was not the true intention of the Soviets regarding Sino-US. relations. This formulation just reflected that the Soviets remained cautious in their relations with the United States; they wanted to avoid provoking the United States during the first years of the Cold War. But privately the Soviets did not want the new CCP government to maintain normal contact with Washington. Mikoyan's many other speeches reflected such an attitude. For example, when he spoke about the economic problems with the CCP leaders on February 2, 1949, Mikoyan did not agree with Ren Bishi's ${ }^{23}$ suggestion about importing 30 tons of raw cotton from the United States due to its shortage on the Chinese market. Mikoyan believed "cotton does have a major role in Chinese national economy, but importing raw cotton from the United States is inappropriate. Cotton production in China should be independent and self-sufficient". Ren had to give in and applaud Mikoyan's opinion in the end. ${ }^{24}$ Thus, it could be seen that the Soviets were not willing to see contacts between the CCP government and Washington, thus even some necessary foreign trade relations were also not approved. Since the CCP already set up its international strategy as the "leaning to one side" policy, they were compelled to agree with the Soviets on these issues.

At the same time, in order to win the trust of the Soviets, the CCP also did their best to maintain an identical position with the Soviet Union regarding

21 "Mikoyan's Conversation with Zhou Enlai and other CCP Leaders on Diplomatic Principles", February 1, 1949, АПРФ, ф. 39, оп. 1, д. 39, л. 17-24; Русско-китайские отношения в ХХ веке, T. V, K. 2, c. 43-48.

22 “Mikoyan's conversation with Mao Zedong on CСР’s domestic policies, February 5, 1949, АПРФ, ф. 39, оп. 1, д. 39, л. 64-73; Русско-китайские отношения в ХХ веке, Т. V, К. 2, с. 72-78.

23 Ren was one of the CCP Politburo members and the Secretary of the Central Committee's Secretariat at the time.

24 "Memorandum of Mikoyan's Conversation with CCP's Leaders on the Chinese economy", February 2, 1949, АПРФ, ф. 39, оп. 1, д. 39, л. 31-38; Русско-китайские отношения в ХХ веке, Т. V, К. 2, с. 52-57. 
the issue of Yugoslavia. On November 30, 1947, before the Xibaipo Period, Mao regarded Yugoslavia as one of the role models worth studying by the CCP, as he said in his cable to Stalin: "After accomplishing the victory of the Chinese Revolution, we should construct our political system like the systems of Soviet Union and Yugoslavia. All other parties and political forces, except the CCP, should leave the political stage. This kind of political system would greatly strengthen the results of the Chinese Revolution". ${ }^{25}$ It was obvious that Mao appreciated Yugoslavia's model at that time. But after June 28, 1948, the day when the CPSU manipulated the Cominform to pass an anti-Yugoslav resolution and expel the CPY from its ranks, the CCP accordingly also changed its position towards the CPY. On July 10, the CC CCP also adopted a resolution on Yugoslavia which fully supported the decision of the Comimform. In addition, on November 7, the voice of the CCP-People's Daily- published an article written by Mao's deputy, Liu Shaoqi. ${ }^{26}$ In this article "On Internationalism and Nationalism", Liu condemned Yugoslav leadership "as bourgeois nationalists", and pointed out that one of CPY's main errors was "not to ally with the Soviet Union, but to go against the Soviet Union". ${ }^{27}$

When Mikoyan visited Xibaipo at the beginning of 1949, Mao and other CCP leaders discussed Yugoslavia several times and they demonstrated their disapproval of Tito's policies. For example, during the discussion with Mikoyan on February 3, Mao asked Mikoyan to present the Yugoslav case. At last, Mao concluded: "Tito is Zhang Guotao, ${ }^{28}$ who is a traitor of the CCP". ${ }^{29}$ In the conversation with Mikoyan on February $5^{\text {th }}$, Mao again stressed his opinion that Comrade Stalin's instruction on the Chinese revolution and his criticism of Yugoslavia were equally precious for him. Because Stalin believed that the Chinese Revolution was part of the world revolution, Mao reiterated that he was Stalin's 'student' and insisted on the policy of aligning with the Soviet Union. ${ }^{30}$ Why did the CCP leaders emphasize the consistent attitude with the Soviet Union on the Yugoslav issue? It was because the CCP leadership was concerned about any possible comparisons between China and Yugoslavia by the Soviets, especially by Stalin. They were concerned that the Soviets regarded Mao Zedong as 'Tito' in China. Any similar parallel would undermine the Sino-Soviet alliance. Nevertheless, their fear was well-founded as later facts showed. In Xibaipo period, therefore, to win the recognition and support of the Soviet Union, the CCP leaders tried to make a clean break with Yugoslavia.

In a nutshell, during the Xibaipo period, together with continuous victories, the CCP gradually adjusted its understanding of the international situation and it sided

25 “Telegram from Mao Zedong to Stalin”, November 30 1947, АПРФ, ф. 45, оп. 1, д. 330, л. 13-17.

26 Liu was one of the CCP Politburo members and the Secretary of the CCP Central Committee at that time.

27 People's Daily, Nov. 7, 1948, Vol. 1/Vol. 2.

28 Zhang Guotao was a founding member and important leader of the CCP and a bitter rival of Mao Zedong. During the Long March, Zhang's armies took a different route from Mao's and were badly beaten by local forces in Gansu. When his depleted forces finally arrived to join Mao in Yan'an, Zhang continued challenging Mao. In 1938, Zhang left the party and defected to the Kuomintang.

29 АПРФ, ф. 39, оп. 1, д. 39, л. 47-53; Русско-китайские отношения в ХХ веке, Т. V, К. 2, с. 62-66.

30 АПРФ, ф. 39, оп. 1, д. 39, л. 64-73; Русско-китайские отношения в ХХ веке, Т. V, К. 2, с. 72-78. 
firmly with the socialist camp. Therefore, the international strategy of the upcoming new regime which was characterized as "leaning to one side" ${ }^{31}$ evolved during this period.

\section{The basic diplomatic principles of the PRC government were gradually formed in Xibaipo}

With the gradual formulation of "leaning to one side" foreign policy strategy, the basic principles of the new regime's diplomacy were finalized in this small mountain village. In Mao Zedong's own style, these principles could be summed up as "setting up another household" and "cleaning the house before entertaining guests". They meant a totally fresh start for PRC's democracy.

Zhou Enlai explained the principle of "setting up another household" as "not recognizing the KMT government's diplomatic relations with other countries, and establishing our new diplomatic relations with these countries on new bases". ${ }^{32}$ The new bases implied mutual respect for each other's sovereignty and equality and cooperation for mutual benefit. As for the principle of "cleaning house before entertaining guests", the first time that Mao put it forward was in his talk with Mikoyan at the beginning of 1949. During this conversation, Mao compared China to a family and he believed the house of this family was dirty because of the existence of "garbage", "fleas" and "bedbugs" etc. He said: "After the liberation, we must carefully clean up our house, clean the dirty things and do well the rectification of the furnishings. Only by restoring good order in the house, can we invite guests to come in. However, we can invite true friends to come in before such works are accomplished, because they will help us do some cleaning. But the other guests have to wait for a while until we want them to come in". ${ }^{33}$ The "other guests" included the United States and other Western capitalist countries. In this period, the CCP already dealt with the foreign affairs on the national level. Relations with other countries were also different from the former foreign relations of the party or of the Yan'an local government.

First, the CCP clearly put forward that its new regime would not recognize the KMT government's diplomatic relations with foreign governments in the future and it would resolutely eliminate the privileges that imperialist countries had obtained from China. The CCP also made this clear: "Many governments of the imperialist countries, especially the United States, helped the reactionary KMT government repress the Chinese people's liberation forces in the past years. So, we cannot recognize the representatives of these countries who were with the KMT government as formal diplomats in the new era of China. Of course we cannot recognize their diplomatic privileges. As long as we take such measures, we can gain the initiative in foreign affairs and eradicate all previous diplomatic humiliations

31 Some scholars pointed out that "leaning to one side" was not only an international strategy of the CCP, but it was also a national strategy. I totally agree with this opinion, but I only discuss its significance in the diplomatic field.

32 Zhou Enlai, “Our Foreign Policy and Mission”, Selected Works of Zhou Enlai, Beijing: People’s Publishing House, 1984, p. 86.

33 Jin Chongji ed., Biography of Mao Zedong (1893-1949), Beijing: The Central Literature Press, 1996, pp. 910-911. 
throughout history. Privileges of imperialist countries in China must be revoked in principle. And the independence and liberation of the Chinese nation must be realized. This is our unchangeable stance". ${ }^{34}$ In other words, the new regime would first clean up the old diplomatic relations and then re-establish diplomatic relations with other countries on the new basis. The future central government would not recognize old diplomatic relations with the Western countries, and it would not inherit the obligations that the KMT government had been committed to. However, the new regime would also like to develop new diplomatic relations with the Western countries, including the U.S. and the UK.

Second, the CCP also emphasized the main precondition of the future regime to develop diplomatic relations with other countries, including the Soviet Union and other socialist countries. This was "equality". The CCP's regime would not be eager to establish diplomatic ties with foreign countries until this main condition was met. Mao also talked about this condition with Mikoyan in Xibaipo. He said: "The basic principles of our diplomacy are mutual equality and mutual assistance." 35 The Directive on Diplomatic Affairs issued by the CC CCP in 1949 pointed out: "We should strive to solve diplomatic issues which are favorable to the Chinese people and can be easily solved. As for the problems which are impossible to solve right now, we should lay them aside. As for the problems which are just harmless or not so important for the Chinese people, we should not be in a hurry to solve them, even though they are easy to solve. As for the problems which are not clear or premature, we shouldn't deal with them haltingly". ${ }^{66}$ In his conversation with Mikoyan on February 1, 1949, Zhou Enlai referred to two proposals on diplomatic recognition of the future national regime. The first proposal was that the CCP would strive for immediate recognition of the new regime by major foreign powers. In this case, he hoped the Soviet Union would be the first country that would recognize the PRC government. The second proposal was "in no hurry" to strive for recognition. "If the foreign governments declared their willingness to recognize the new government, we would not reject them, but we would not welcome them either". Zhou hinted that the second proposal would last for more than one year if it was chosen to be implemented, and the basis for this second proposal was the CCP belief that its new regime would earn the recognition sooner or later in the future. Zhou said that he personally thought the second proposal was better. If the new government adopted the second proposal, it could be free to curb all foreigners' privileges in China, opposition of foreign governments notwithstanding. Therefore, the PRC government would limit the rights of foreign citizens in China and supervise their activities. ${ }^{37}$

34 "The Directive on Diplomatic Affairs", January 19, 1949. The State Archives Administration of the People's Republic of China, Collected Documents of The CPC Central Committee (Vol. 18), Beijing: The Central Party School Press, 1992, p. 44.

35 "Memorandum of Mikoyan's conversation with Mao Zedong on the united government in China", January 31, 1949, АПРФ, ф. 39, оп. 1, д. 39, л. 7-16; Русско-китайские отношения в ХХ веке, Т. V, K. 2, c. 37-43.

36 "The Directive on Diplomatic Affairs", January 19, 1949. The State Archives Administration of the People's Republic of China, Collected Documents of The CPC Central Committee (Vol. 18), Beijing: The Central Party School Press, 1992, p. 44.

37 “Mikoyan's conversation with Zhou Enlai and other CCP leaders on diplomatic principles", February 1, 1949, АПРФ, ф. 39, оп. 1, д. 39, л. 17-24, Русско-китайские отношения в ХХ веке, T. V, K. 2, c. 43-48. 
Third, the diplomacy of the future regime must be independent. In the same conversation with Mikoyan, Zhou Enlai especially stressed the principles of the CCP's diplomacy, and the first of them was "independent foreign policy". ${ }^{38}$ Five Principles of Peaceful Coexistence which have been present in the PRC's diplomacy up till the present were formulated at this time. The principle of independence was not only applied to the Western countries, like the U.S. and the UK, but it was also used in establishing relations with socialist countries. Although, The Directive on Diplomatic Affairs asked the department of foreign affairs to distinguish socialist countries from capitalist countries, nevertheless "as socialist countries haven't yet established formal relations with the Chinese people's regime, just like other countries, we have to regard their representatives, including their military officers and agencies in China, as foreign civilians and informal foreign agencies". ${ }^{39}$ This reflected consistency in CCP's foreign policy and its independence from the socialist camp.

In addition, the CCP was also trying to clean up the unequal treaties existing between the Soviet Union and China. On February 3, 1949, during his talks with Mikoyan, Mao tentatively put forward a question: "There is a Chinese woman who was a member of the KMT Legislative Committee and she declared that, if the CCP could recover the territory and sovereignty of Port Arthur from the Russians, it would be a great achievement for the Chinese nation." Mao immediately added that he personally thought that this woman did not understand national politics. ${ }^{40}$ The question raised by Mao was soon reported to the Central Committee of CPSU by Mikoyan and it drew Soviet leaders' attention. The CC CPSU instructed Mikoyan to reply to Mao like this: "On the issue of the Sino-Soviet Treaty of Friendship and Alliance, the CPSU believes the treaty is unequal. But it also believes that the purpose of complying with this treaty at present is to prevent the KMT government from colluding with Japan and the United States against the Soviet Union and the Chinese Revolution. The Soviet government decided to abrogate from this treaty in the future. After signing the peace treaty with Japan, we will withdraw our troops from Port Arthur. Of course, if the CCP believes immediate withdrawal is appropriate, we are also prepared to implement it right now. As for the Chinese Manchuria Railway Treaty, the CPSU does not consider it an unequal treaty. The main reason was that this railway had been built by Russian capital. But the CPSU also believed that the principle of equality was not fully respected in this treaty. Therefore, the CPSU is prepared to discuss this issue with the CCP as brothers, until we solve this problem completely". ${ }^{41}$ The CCP, of course, could not ask the

38 "Mikoyan's conversation with Zhou Enlai and other CCP leaders on diplomatic principles", February 1, 1949, АПРФ, ф. 39, оп. 1, д. 39, л. 17-24; Русско-китайские отношения в ХХ веке, T. V, K. 2, c. 43-48.

39 "The Directive on Diplomatic Affairs", January 19, 1949. The State Archives Administration of the People's Republic of China, Collected Documents of The CPC Central Committee (Vol. 18), Beijing: The Central Party School Press, 1992, p. 44.

40 "Memorandum of Mikoyan's conversation with Mao Zedong on cooperation between the CCP and the CPSU", February 4, 1949, АПРФ, ф. 39, оп. 1, д. 39, л. 54-62; Русско-китайские отношения в ХХ веке, Т. V, К. 2, с. 66-72.

41 "Memorandum of Mikoyan's conversation with Mao Zedong on urgent political problems", January 31, 1949, АПРФ, ф. 39, оп. 1, д. 39, л. 78-88; Русско-китайские отношения в ХХ веке, T. V, K. 2, c. 81-87. 
Soviets to withdraw their troops when it really needed support from the Soviet Army in the Civil War. But the generous statements of the CPSU surprised the CCP leaders greatly and motivated them to decide to ally with the Soviet Union. The issue of the treaties signed between the Soviet Union and China in the Xibaipo period established a good foundation for signing a new treaty between them after the establishment of the PRC government.

Fourth, in the Xibaipo period the CCP focused attention to the economic and cultural undertakings controlled by the foreigners, but it did not formulate specific approaches to all these problems. The Directive on Diplomatic Affairs issued in 1944 by the CC CCP just stipulated the attitudes and approaches with regards to foreigners. But when the complete victory on the mainland of China was in sight, after the central party organs of the CCP had moved to Xibaipo, CCP's new Directives on Diplomatic Affairs issued on January 19, 1949 were much more specific. The Directives on Diplomatic Affairs issued in 1949 divided the foreign affairs and foreigners' activities into 15 categories, including diplomatic relations, foreign capital contacts, foreign trade, customs taxes, foreign missionaries, schools run by foreigners, hospitals run by foreigners, foreigners' newspapers and news agencies, foreign journalists, etc. The "directive" also stipulated definite provisions for each category. Except for the foreign-related activities which caused tangible harm to the Chinese people, all other activities were subjected to the status quo. However, all foreigners and foreign-related undertakings were asked to submit to the CCP's administration and accept registration and inspection. For example, regarding the foreign capital contacts, the "directive" stated: "As for all economic privileges, business enterprises, factories and other investment, whatever belonging to foreign persons or countries, we cannot give formal legal recognition to them, but we are not eager to deal with them at present, no prohibition, no confiscation". However, the "directive" also detailed provisions that constituted "the greatest harm to Chinese people's economic life, such as financial speculations," and "greatest infringement on China's national sovereignty, such as inland navigations, etc." The theme of these provisions was "an immediate ban". But some other foreign-related undertakings such as foreign banks had not been asked to close down. They were asked to report their capitals, accounts and business affairs to the local CCP's governments and wait for the decisions of local authorities. Foreign insurance companies, especially marine insurance companies, cannot be treated in a harsh manner" ${ }^{42}$ On March 3, 1949, the Second Plenary Session of the Seventh Central Committee of the CCP further emphasized: "The economic enterprises and cultural establishments which are directly run by the imperialists have to be permitted to exist for some time. We must distinct these undertakings and deal with them separately and properly".43 Thus, in the Xibaipo Period, the CCP's diplomatic principles regarding foreigners and foreign-related economic and cultural enterprises were formulated. But some specific questions in this field had not been solved yet.

\footnotetext{
42 "Directive on Diplomatic Affairs", January 19, 1949. The State Archives Administration of the People's Republic of China, Collected Documents of The CPC Central Committee (Vol. 18), Beijing: The Central Party School Press, 1992, p. 44.

43 The State Archives Administration of the People's Republic of China, Collected Documents of The CPC Central Committee (1948-1949), Beijing: The Central Party School Press, 1987, p. 595.
} 
With the progress of the Chinese Civil War, the People's Liberation Army not only defeated the KMT army, but also eradicated certain privileges of imperialist countries in China. The remaining privileges included the barracks garrisoned by the troops of the Western countries in Beijing, Tianjin and Shanghai. They also included the free navigation of foreign vessels in the inland rivers of China and old rules of China's customs which were favorable to the foreigners. These privileges were soon revoked by the administration of the PRC government according to the diplomatic principles established in Xibaipo. In January 1950, the Beijing Military Control Commission announced the expropriations of the barracks' property belonging to the United States, France, and the Netherlands in Beijing. Soon the British barracks were also expropriated. The Western countries' barracks in Tianjin and Shanghai were also subjected to expropriation. In this month, the central government of the PRC also adopted the Decision on Tariff Policy and Customs. In April and May of 1951, this government announced the PRC Interim Customs Law and determined the new customs tariff. At the same time, privileges to trade with the foreigners were totally reverted to state institutions. No enterprise could conduct foreign trade unless it had the exportimport licenses. The tariff sovereignty of China had been fully restored. In July 1950, the Finance Committee of PRC's Central Government issued instructions on shipping management which required the shipping affairs in whole country to be managed in the unified manner by the Central Government. Afterwards, foreigners' ocean liners could not enter inland rivers without the permissions of the Chinese government. The management of navigation in China's inland rivers was fully restored. After all, in less than one year's time, the Central Government of the PRC basically eliminated the privileges of imperialist countries in China.

After the establishment of the new regime, it insisted on the principle of equality and independence when it established diplomatic relations with the other countries as it was stipulated in The Directive on Diplomatic Affairs issued in Xibaipo. The Central Government of the PRC soon established diplomatic relations with socialist countries such as the Soviet Union, Bulgaria, Romania, Hungary, Czechoslovakia, Poland, Mongolia, Albania, Democratic Republic of Vietnam and the German Democratic Republic. These diplomatic recognitions did not need any preparatory negotiations. But for other nationalist countries, such as Burma, India, Pakistan, Ceylon and Afghanistan, and Western capitalist countries such as the United Kingdom, Norway, Denmark, Finland, Sweden, Switzerland and Netherlands, things were different. Before establishing formal diplomatic relations, the new Chinese government conducted serious negotiations, asked them to clarify their attitude towards the KMT government and explicitly insisted that the Central Government of the PRC was the only legitimate government of China. These diplomatic actions reflected that the new regime's diplomacy was strictly principled and highly flexible.

As for the capitalist countries' economic undertakings in China, the newly founded government dealt with them according to the Decisions of the Second Plenary Session of the Seventh Central Committee of the CPC which was held in Xibaipo. It adopted a distinctive policy "according to the nationalities, systems, industries and other various specific conditions". Therefore, the new Chinese government carried out detailed investigations regarding the foreign-related 
enterprises. ${ }^{44}$ After the outbreak of the Korean War, on December 28, 1950, the Central Government of the PRC issued a special order to control the American assets and enterprises located in China because Washington had implemented similar policies with regards to China's properties in America. For Britain, France and assets of other capitalist countries in China, also due to their hostile attitudes towards the PRC, many had been nationalized before the end of 1953 . Some other enterprises continued to work, but later on they slowly disappeared due to the Western economic embargo and China's socialist transformation of the trade and industry. As for the foreign cultural establishments, with the victory of the CCP, most foreign news agencies and propaganda agencies had to stop their activities in China. As far as religion was concerned, the Three-Self Patriotic Movement of the Protestant Churches in China began in 1951, and it was completed in 1954. After this movement which had three famous principles of self-governance, selfsupport (i.e., financial independence from foreigners) and self-propagation (i.e., indigenous missionary work), most of the Chinese religious organizations severed their relations with their foreign churches. The institutions dealing with culture, education, health and relief etc., which were run by foreigners or accepted foreign capitals, were also treated according to the principles established during the Xibaipo Period. The Directive on Diplomatic Affairs stated: "Foreign owned schools can be allowed to maintain their status quo tentatively. But all presidents of these schools must be Chinese. They also have to report their sources of funding. Their curriculums need to be formulated according to the same rules implemented in other schools. As far as the relief agencies run by foreigners were concerned, only if their international cooperative organizations were not adverse to our independence and national sovereignty, they can receive foreign assistances and relief. As for foreign newspapers and journals, we could tentatively ignore them. However, they are required to send their newspapers throughout the year to us and to have them registered. The foreign news agencies have to be banned from reporting news, not to mention secretly setting up radio stations". 45

To sum up, during the Xibaipo Period, in addition to the formulation of the new international strategy of the future regime with the alliance with the Soviet Union at its core, the CCP also established relatively specific diplomatic principles and policies.

\section{Staff formation and organizational preparations for the diplomacy of the future regime in the Xibaipo Period}

If the CCP wanted to implementabrand-new foreign policy of independence and autonomy, it had to disband KMT government's diplomatic institutions and abandon the use of KMT diplomats. It had to set up its own diplomatic institutions and develop its own diplomatic personnel. This was something that had also been done in the Xibaipo Period.

44 Contemporary Chinese Diplomacy, Beijing: China Social Sciences Press, 1990, p. 20.

45 The State Archives Administration of the People's Republic of China, Collected Documents of The CPC Central Committee (1948-1949), Beijing: The Central Party School Press, 1987, p. 516; Contemporary Chinese Diplomacy, Beijing: China Social Sciences Press, 1990, p. 22. 
During the period of the new-democratic revolution in China, members of the CPC who were engaged in foreign affairs and had diplomatic experience came from three different institutions. The first institution was the Foreign Affairs Office in the CC CCP's Southern Bureau. The second Institution was the Yan'an Foreign Affairs Department in the CCP's Central Military Commission. And the third institution was the Military Executive Headquarters in Beiping. CCP members in these three institutions became the driving force of CCP's foreign affairs and most of them had also gathered in Xibaipo.

According to the memoirs of Ling Qing, who was one of the old diplomats in new China, all the staff engaged in foreign affairs retreated from Yenan in March 1947. They crossed the Yellow River and came to the Shanxi District of Jinsui Revolutionary Base. ${ }^{46}$ On May 1, 1947, Ye Jianying ${ }^{47}$ gathered all these foreign affairs workers in the small town named Sanjiao of Linxian County, Shanxi Province. Ye announced the establishment of the Central Foreign Affairs Group of the CCP's Central Committee, and he published the organizational structure and personnel arrangements of this Group. The president of the Group was Ye himself and the vice-president was Wang Bingnan. There were three offices in the Group. One was the Research Office, one was the Press Office and the other was the Compilation and Propaganda Office. ${ }^{48}$ According to the instructions coming from Zhou Enlai, Group members should do some basic preparations for the future diplomatic careers and exercise their diplomatic skills in the current, relatively quiet environment. The core work of the Group at that time was to translate the famous works of Mao Zedong, translate and edit some reference books about the United States, and compile a few booklets about the basic policies of the liberated areas. "You should spend 1 or 2 years doing this, and concentrate all your efforts on it. The individual Group members should spend at least six months participating in the Land Reform Movement. Thus you would be taught by the grassroots. In all, you must strengthen your political qualities and English skills during this period." ${ }^{9}$

In April 1948, the Central Foreign Affairs Group moved to Xibaipo together with other key central party organs. The public name of the Group was the English Class in the Central Workers' School. The Group was guided by the CC CCP. The

46 Jinsui Revolutionary Base was established in the Northwest of Shanxi Province and Southeast of Inner Mongolia as Jinsui Anti-Japanese Base by the CCP's army in 1937, after the Japanese army had invaded and occupied Northern China. After the Chinese Civil War began, it became one of the most important CCP revolutionary bases .

47 Ye Jianying was one of the ten Marshals of the People's Liberation Army. He had been assigned as the Chief Representative of CCP in the Military Executive Headquarters of Beiping in 1946. He came back to Yenan in 1947 and served as the Secretary of the CCP Rear Central Committee, the Deputy Chief of Staff in the CCP Central Military Commission and in the People's Liberation Army. He held a concurrent post as the President of North China Military University since 1948.

48 Ling Qing, “From Yan'an Cave to Xibaipo”, International Politics Studies, Vol. 3, 2004, pp. 42-54. Organization Department of the CPC Central Committee, the Party History Research Center of the CPC Central Committee and the State Archives Administration of the People's Republic of China, Historical Data Collection on the Organization of the CCP, Beijing: Central Party School Press, 2000, pp. 66-67.

49 “Zhou Enlai's letter to Wang Bingnan", July 29, 1947, cited from Gao Liang, "New China Diplomacy was Created Like This - Rereading Zhou Enlai's Five Letters to Wang Bingnan", Yan Huang Chun Qiu, Vol. 4, 1998, pp. 14-19. 
Group continued its preparations for future diplomatic work by preparing all kinds of documents, research reports, and policy recommendations. ${ }^{50}$ During the Xibaipo Period, the primary objective set for the Central Foreign Affairs Group by the Central Committee was "training and storing cadres to meet the needs of future diplomatic work" ${ }^{51}$ It was precisely at this period that not only had most of the old diplomatic personnel been gathered in this small village for some time, but also a lot of new personnel for diplomacy had been recruited. The Diplomatic Policy Research Office and the Foreign Language School were added to the already existing Research Office, Press Office, and Compilation and Propaganda Office.

During this period, the CC CCP devoted its attention to education and training of foreign affairs personnel in institutions such as the special foreign language school run by the Foreign Affairs Group. This school was established in August of 1948, whose public name was the English School of North China Military University. But it was run by the North China Military University and the Foreign Affairs Group at the same time. ${ }^{52}$ In January 12, 1949, Zhou Enlai met with the staff of the Central Foreign Affairs Group and gave a speech on the future of diplomatic policy. His speech was a comprehensive instruction to the CCP's diplomats on the eve of the founding of the new regime. After the PLA seized cities with diplomatic offices, Zhou reaffirmed that certain principles and policies had to be followed in diplomatic work. He also emphasized the necessary discipline in dealing with foreign affairs. Zhou said: "Diplomats are civilian 'PLA cadres'. Foreign affairs have an important influence on the outside world. So, any foreign-related affair is of great importance. The Central Government is the only one who can conduct diplomatic affairs. No local government can freely decide on its own diplomatic policy". ${ }^{33}$ Rules defined in Zhou's speech had become the norm that the diplomatic personnel of the PRC government had to generally follow.

Diplomatic talents integrated and trained in Xibaipo played key roles in the foreign affairs of the PRC government right after it was formed. For example, in January 1949 some members of the Central Foreign Affairs Group marched to Tianjin, thus participating in taking over the power from the KMT government. They took charge of the foreign affairs of Tianjin and conducted contacts with foreigners in this city. Other members of the Group did the same in major cities like Beijing and Shanghai. In October of this same year, after the Central Government of the PRC had been established, all members of the Group were transferred to the Ministry of Foreign Affairs of the PRC. The first formal diplomatic letter of the PRC to other countries was sent out by the original members of the Central Foreign Affairs Group such as Hanxu and Ke Bainian, who rode a bicycle to send the letter

50 Organization Department of the CPC Central Committee, the Party History Research Center of the CPC Central Committee and the State Archives Administration of the People's Republic of China, Historical Data Collection on the Organization of CPC, Beijing: The Central Party School Press, 2000 , p. 67.

51 Ling Qing, “From Yenan Cave to Xibaipo", International Politics Studies, Vol. 3, 2004, pp. 42-54.

52 Organization Department of the CPC Central Committee, the Party History Research Center of the CPC Central Committee and the State Archives Administration of the People's Republic of China, Historical Data Collection on the Organization of CPC, Beijing: The Central Party School Press, 2000, p. 67.

53 Yang Shangkun, Yang Shangkun Diaries, Beijing: The Central Literature Press, 2001, p. 14; Ling Qing, "Zhou Enlai's Early Indications about Foreign Affairs", World Affairs, Vol. 6, 2008, pp. 50-52. 
to each embassy or consulate of foreign countries in Beijing. Many members of the Group later became excellent diplomats. Huang Hua, Zhang Wenjin, and Wang Bingnan were the outstanding figures in China's diplomacy. In 1971, after the PRC restored its lawful seat in the UN, Huang Hua served as PRC's first ambassador to the United Nations; from 1977 to 1982, he was also appointed as the Chinese Foreign Minister. As for Zhang, he took part in the important work of normalizing Sino-American relations; and in 1978, Zhang was assigned as the Deputy Foreign Minister. Wang helped Zhou Enlai and other leaders form the Ministry of Foreign Affairs of the PRC and conduct the Chinese people's diplomacy. From 1955, he had been appointed the ambassador to Poland. At the same time, he had been in charge of the Sino-US ambassadorial talks for nine years until his return in 1964. Beside these famous figures, Dong Yueqian, Han Xu, Xu Danian, Ke Bainian, Ling Qing, Wu Qing etc. also held important posts in the Ministry of Foreign Affairs of the PRC and made significant contributions to China's diplomacy.

After the establishment of the new regime, due to the expansion of diplomatic efforts, the need to expand diplomatic forces became urgent. The Ministry of Foreign Affairs deployed a large number of staff from the military, the local government, the foreign language schools and other institutions. Even so, the original members of the Central Foreign Affairs Group still held the most important posts of the Ministry for a few years. For example, the inner cadre statistics of the Ministry of Foreign Affairs on August 25, 1950, showed that among 449 cadres, the number of personnel from the Group and the local foreign Affairs Offices was 80 , still accounted for $17.8 \%$ of the total number of diplomats and was still the second biggest group inside the Ministry (The first biggest group was the staff from the language schools). The most important thing was that these officials occupied the vast majority of the upper positions inside the Foreign Ministry. ${ }^{54}$ This was consistent with Zhou Enlai's expectations. According to an old diplomat Kang Jimin's memoirs, Premier Zhou Enlai had pointed out that at the beginning of the Ministry of Foreign Affairs, its staff constituted of three groups of people: generals from the PLA and some local government leaders served as ambassadors and held other leading positions; members of the Central Foreign Affairs Group and some underground workers who had some experience in foreign affairs and could do professional works in operational positions as branch-level leaders; young intellectuals were also taken into the Foreign Ministry and they could work at the grassroots level as the professional staff. ${ }^{55}$ Therefore, the members of the Foreign Affairs Group who had been trained in Xibaipo were the backbone of China's new diplomacy.

These new foreign affairs agencies established by the CCP in the liberated areas during the Civil War represented the organizational foundation for the future regime's local foreign affairs. By the end of 1948, the CC CCP began to establish the Tianjin Foreign Affairs Agency and the Beijing Foreign Affairs Agency. As for the Beijing Foreign Agency, it took over the management of the Beijing office of KMT government's Information Bureau, the Representative Office of the KMT's

54 The People's Republic of China Ministry of Foreign Affairs Archives, No. 122-00347-01, p. 3.

55 Kang Jimin, "Yan Baohang and the Diplomatic Etiquette of New China", Bainianchao, Vol. 11, 2010, pp. 51-56. 
Ministry of Foreign Affairs Office and the Diplomatic Office of the local Beijing government. This Agency was named the Alien Affairs Office and took charge of all foreign-related matters in Beijing after its liberation. But it was just an executive body and it had to follow instructions from the CCP's division in Beijing and it had to report all major issues to the CC CCP. This office opened to the public on February 14, 1949, while in March the new regime, the People's Government of Beijing, decided that the Alien Affairs Office was directly led by the mayor of Beijing and it could establish its own policy-study agency. ${ }^{56}$ With the gradual liberation of other cities, a lot of foreign affairs agencies were set up in the same way. The staff of these agencies consisted of former KMT diplomatic personnel and former members of the Central Foreign Affairs Group of the CCP. The Directive on Diplomatic Affairs issued in Xibaipo also specified the rules that on all levels foreign affairs agencies had to be established in the liberated areas and they had to follow these instructions: "Every city that has any alien residents has to set up the alien management office. This office will take charge of the registration, inquiring, and inspection of foreign nationals' living, communication and profession. It will also issue passports to aliens. Some special cities also have to set up foreign affairs offices. These offices will take charge of the affairs related to foreign nationals (such as factories, enterprises, banks, companies, shops, schools, hospitals, churches, organizations, newspapers, periodicals, news agencies, etc.). They will deal with registration, inspection and grant permission for these affairs". ${ }^{57}$

The central diplomatic agency of the future regime was also established during the Xibaipo period. During their conversations with Mikoyan in the February of 1949, CCP's leaders also reported their plans on the establishment of new China's Ministry of Foreign Affairs. In Mikoyan's report to the CC CPSU we can see: "When I asked Zhou Enlai which party would be responsible for the future operation of the Foreign Ministry, he answered without hesitation that the Minister must be a member of the CCP. In addition, he believed that one deputy minister has to be a communist, while the other can be a non-party person". ${ }^{58}$ The CCP leadership took the stand that, the new Chinese Foreign Ministry must follow the leadership of the party in its entirety. It also had to reject the old regulations of the KMT government and eliminate all KMT's personnel arrangements. This was the policy of "clean slate".

To conclude, the Xibaipo Period in the history of CCP represents a special and important transition period. CCP's foreign policy-related activities gradually evolved from party's external communication to national diplomacy. The CCP leaders carefully observed and analyzed the international situation and they made an important choice at the beginning of the Cold War. They chose to ally with the Soviet Union and suffer the consequences of confrontation with the United

56 Wang Erbao, “Construction of New China's Local Diplomatic System - Research on the Diplomatic Rules of Beijing", Contemporary China History Studies, Vol. 2, 2010, pp. 90-96.

57 The Directive on Diplomatic Affairs, January 19, 1949. The State Archives Administration of the People's Republic of China, Collected Documents of The CPC Central Committee (Vol. 18), Beijing: The Central Party School Press, 1992, p. 48.

58 “Mikoyan's conversation with Zhou Enlai and other CCP Leaders on Diplomatic Principles", February 1, 1949, АПРФ, ф. 39, оп. 1, д. 39, л. 17-24; Русско-китайские отношения в ХХ веке, T. V, K. 2, c. 43-48. 
States. In this period, the corresponding diplomatic principles and foreign policies gradually evolved. While many of the CCP's own diplomats had been gathered and trained in this small village, the foreign affairs institutions had been set up during the process of taking over the cities from the KMT government. All this activity laid a solid foundation for the future regime's diplomacy. Therefore, it can be said that the CCP's diplomatic activity in the Xibaipo Period in fact constituted the beginning of the People's Republic of China new diplomacy.

\section{Резиме}

Др Хе Јенћинг

\section{Почетак кинеске дипломатије: Дипломатска активност кинеског комунистичког режима током сибаипо периода (мај 1948 - март 1949)}

Кључне речи: сибаипо период, дипломатија Народне Републике Кине, кинеско-совјетски односи, кинеско-амерички односи

Сибаипо период у историји Комунистичке партије Кине је посебан и важан период. Активности КПК у односима са иностранством су се полако развијале, почевши од веза које је успостављала партија па све до развитка националне дипломатије. Почетком хладног рата вођство КПК је пажљиво пратило и анализирало међународну ситуацију и донело важну одлуку. Изабрали су савезништво са Совјетским Савезом и као последицу трпели конфронтацију са САД-ом. Током овог периода, одговарајући дипломатски принципи и спољна политика земље су се полако формирали. Док се већина дипломатског кадра КПК налазила у малом селу Сибаипо, институције спољне политике су осниване током процеса преузимања градова од владе Куоминтанга. Све ове активности биле су добра основа за будућу дипломатију режима КПК. Дакле, може се рећи да је дипломатска активност током сибаипо периода поставила основе нове кинеске дипломатије. 